\title{
The Role of Micro Enterprises in Employment and Income Generation: A Case Study of Timergara City Dir (L) Pakistan Taj Hassan* and Bilal Ahmad
}

Department of Economics, University of Malakand, Khyber Pakhtunkhwa, Pakistan

\begin{abstract}
In this study an attempt is made to assess the role of micro enterprises creating employment opportunities and income generation opportunity in Timergara District Dir Lower, KPK Pakistan. During the study primary data were collected from the owners of 80 micro enterprises. Questionnaire was used as data collection instruments. For Data analysis descriptive statistical tools such as tables, frequency distribution and percentages, and inferential statistical tools such as regression analysis were used to describe the responses on the role of micro enterprises. The study elaborate that there is some positive growth rate of micro enterprises in Timergara City. Regarding employment creation these micro enterprises created around 4.75 average numbers of employees per micro enterprise. The total number of employees in 80 enterprises was 380 employees. Most of the enterprise owners (42.5\%) get average monthly income from Rs.53000 to Rs.89000 and each employee in the enterprise get average income of Rs.11997 per month. The total average monthly sale of 80 enterprises in Timergara City is Rs.61000000. Besides this the enterprises also faced some constraints during start-up time and also face constraints during operation, such as financial shortage, security, high rent and energy shortage. To conclude that, micro enterprises play a great role in reducing unemployment and also play a great role in income generation to the owners and employees. Based on the major findings a number of policy recommendations are drawn. Among these the access to credit, price control, government check and provision of energy is very important for the development of these micro enterprises.
\end{abstract}

Keywords: SMEs; Micro Enterprises; Employment; Income; Dir lower Pakistan

\section{Introduction}

Micro Enterprises play an important role in employment creation and income generation. These Small Scale Enterprises are more efficient in the nation's economy as they create employment and can provide income generation opportunity for low income groups. The small scale enterprises provide the entrepreneurial culture and boast of the economy against economic crises, such as low per capita income, poverty and unemployment. According to Government of Pakistan, SMEs is one of the four important drivers of growth for the Pakistan economy.

The SMEs sector is highly labor intensive and this sector provides employment to the major part of non-agriculture labor force in Pakistan [1].

Different authors define SMEs differently. Some of the authors differentiate SMEs in terms of capital assets while other authors differentiate SMEs on the basis of skill and turnover. The Bolton Committee formulated "economic" and "statistical" definition of SMEs according to which an SME is an independent firm, which has relatively small share of its market place, and managed by the owners themselves, or part owners personally, and not by the medium of formalized management structure. According to statistical definition SMEs are characterized by the size, contribution to GDP, employment opportunities provided by these firms, exports, and their contribution to national economy $[2,3]$. According to the SMEDA "micro enterprises involve those small enterprises that have fixed capital of Rs.2.5 million and the number of employers does not exceed 10 ".

According to a World Bank study, MSME's in Pakistan account for $30 \%$ of GDP and contribute to $25 \%$ of export earnings. According to Gallup survey in 2004, MSME in Pakistan employed $80 \%$ of the non-agriculture labor force. As the sector moves towards achieving growth and sustainability through greater market segmentation and product diversification, enterprise lending has become an increasingly important opportunity for microfinance providers (MFP's).

Pakistan's industrial sector is geographically diversified. The largescale industries are, mostly located in urban areas whereas most of the Micro Enterprises are located in small towns and rural areas. These Micro Enterprises units located in rural localities are of great importance for the provision of employment to poor rural workers. Hence the SMEs sector is an important potential sector for employment creation and income generation for the poor class.

\section{Literature Review}

Agyapong discusses the role of micro, small and medium enterprises (MSMEs) in poverty alleviation in Ghana. The author is of the view that town and rural based MSMEs help to create jobs and increase income of the people. This increased income helps the people to obtain better schooling, health facilities and empowers them to get rid of vicious circle of poverty. Furthermore, growth in small and medium enterprises (SMEs) also contributes to human capital through on job training. The author is also of the view that MSMEs also contribute in the increase of tax revenue of the government [4].

According to the study of Bereket in Mekelle city, the micro enterprises created jobs for many individuals. The average employees of SMEs are 7.05 per SME in Mekelle city. There is an increase in average employees of MSEs from year to year. Most of the SMEs owners (44\%) annual average income of five years is between 30,000-60,000 birr and $42 \%$ of the employees get annual average income of five years from 7201-8400 birr.

In Pakistan most of the people live in villages and are engaged in agriculture. As according to Khaleeq and Nasim, in the rural areas of

*Corresponding author: Taj Hassan, Department of Economics, University of Malakand, Pakistan, Tel: (+92)3429384122; E-mail: tajhassan555@gmail.com

Received January 09, 2016; Accepted January 30, 2016; Published February 03, 2016

Citation: Hassan T, Ahmad B (2016) The Role of Micro Enterprises in Employment and Income Generation: A Case Study of Timergara City Dir (L) Pakistan. Int J Econ Manag Sci 5: 318. doi:10.4172/2162-6359.1000318

Copyright: ( 2016 Hassan T, et al. This is an open-access article distributed under the terms of the Creative Commons Attribution License, which permits unrestricted use, distribution, and reproduction in any medium, provided the original author and source are credited. 
Pakistan the poverty ratio is very high. Here the poverty can be reduce through the establishment of SMEs, as Khan conducted study which shows that the government of Bangladesh overcome rural poverty by the establishment of Micro Enterprises financed by Grameen Bank. During that period the rate of reduction in poverty was $8.5 \%$ annually [5].

Beck et al. explored the relationship between SMEs, growth and poverty find a strong and strong relationship between the importance of SMEs and growth in GDP per capita. The study could not find enough evidence of the poverty alleviating impact of SMEs in a sample of 45 countries. However, it has been deduced that SMEs are labor intensive so growth in these enterprises increases employment more than the large scale industries' growth.

Ghazala, studied Micro Enterprises and their linkages with rest of the economy [6]. She studied that, micro enterprises are most important and valuable businesses along with other businesses. The Micro Enterprises provides employment to 4-5 persons per micro business. Thus the Micro Enterprises are more labor intensive. In capital formation the Micro Enterprises will contribute positively, on average these enterprises increased their total investment by $66 \%$ and the increase in non-capital expenses are $50 \%$. The contribution of Micro Enterprises in value addition is high (Rs.2.19 for every rupee spent on raw-material purchases) compare to other business and concludes that Micro Enterprises contribute on average Rs.52 thousands to Rs.59 thousands to family welfare on monthly basis [7]

Studies for the importance of SMEs for the contributions in economic growth and development of the economies have been recognized. SMEs employ much more labor force than the huge multinational corporations. SME sector has been a source of concern for the policy makers for the accelerated growth in developing nations. SMEs are a major source of potential employment in low income economies. There for these enterprises are considered to be the "engine of growth" for attainment of growth objectives in developing nations [8].

Levitsky described micro enterprise as a very small business consisting of a single self-employed person or a family person. $\mathrm{He}$ noted that such enterprise were the main source of livelihood for up to half of population of the developing countries [9]. Further he noted that in the in the past this important sector was often referred to as informal sector and giving had a less attention, but with the passage of time this sector got attention of the multilateral and bilateral agencies and non-governmental organization, who were searching for ways to help improve the effectiveness of these micro enterprises operations and enable them to make a greater contribution to the development of the third world [10-12].

\section{Data and Methodology}

This study investigates the role of micro enterprises in employment and income generation, a case study of timergara city district dir lower kpk Pakistan. The needed Data were collected using questionnaire schedule and the collected Data were analysed, using statistical and econometrics tools. The Data was collected from 80 micro enterprises of Timergara City, Dir Lower. One of the sampling method known as stratified random sampling was used. Here five categories of Micro Enterprises are taken from Medical Stores, Sweets and Bakers, Sweets Stores, Electrical Appliances Stores, Books and Stationary Stores as shown in Table 1. The response of the questionnaires was coded, tabulated and analyzed under Statistical Packages for Social Sciences (SPSS) and Econometrics application such as E Views. The multiple regression models have been used to incorporate the role of micro

\begin{tabular}{|c|l|c|c|}
\hline S. No & Enterprise & $\begin{array}{c}\text { Sample } \\
\text { size }\end{array}$ & Percentage (\%) \\
\hline 1 & Medical Stores & 15 & 18.75 \\
\hline 2 & Sweets and Bakers & 15 & 18.75 \\
\hline 3 & Sweets Stores & 20 & 25 \\
\hline 4 & Electrical Appliances Stores & 20 & 25 \\
\hline 5 & Books and Stationary Stores & 10 & 12.5 \\
\hline Total & & 80 & 100 \\
\hline
\end{tabular}

Source: Own Survey.

Table 1: Sample size.

\begin{tabular}{|c|c|c|}
\hline Age (years) & Frequency & Percent \\
\hline $20-30$ & 18 & 22.5 \\
\hline $31-40$ & 32 & 40 \\
\hline $41-50$ & 22 & 27.5 \\
\hline 51 and above & 8 & 10 \\
\hline Total & 80 & 100 \\
\hline
\end{tabular}

Source: Own Survey.

Table 2: Age of the owners (years)

\begin{tabular}{|c|c|c|c|c|c|c|c|c|c|c|c|c|}
\hline \multirow[t]{2}{*}{ Age } & \multicolumn{2}{|c|}{ Medicine } & \multicolumn{2}{|c|}{ Sweets } & \multicolumn{2}{|c|}{ Bakers } & \multicolumn{2}{|c|}{ Books } & \multicolumn{2}{|c|}{ Electronics } & \multicolumn{2}{|c|}{ Total } \\
\hline & Freq. & $\%$ & Freq. & $\%$ & Freq. & $\%$ & Freq. & $\%$ & Freq. & $\%$ & Freq. & $\%$ \\
\hline $20-25$ & 54 & 36.4 & 18 & 36 & 44 & 53.6 & 28 & 50 & 22 & 50 & 166 & 45.2 \\
\hline $26-31$ & 50 & 33.7 & 14 & 28 & 20 & 24.3 & 12 & 21.4 & 12 & 27.2 & 108 & 27 \\
\hline $32-37$ & 42 & 28.3 & 6 & 12 & 12 & 14.6 & 4 & 7.1 & 10 & 22.2 & 74 & 17.8 \\
\hline $38-43$ & 2 & 1.3 & 8 & 16 & 4 & 4.8 & 2 & 3.5 & - & - & 16 & 5.1 \\
\hline $43+$ & - & - & 4 & 8 & 2 & 2.4 & 10 & 17.8 & - & - & 16 & 5.6 \\
\hline Total & 148 & 100 & 50 & 100 & 82 & 100 & 56 & 100 & 44 & 100 & 380 & 100 \\
\hline
\end{tabular}

Source: Own Survey.

Table 3: Age of the employees.

enterprises in employment. In the modal the enterprise employment level is the function of enterprise monthly sale and enterprise life. The following multiple regression model has been estimated:

Model: $\mathrm{Yi}=\alpha+\beta 1$ Monthly sale $+\beta 2$ Life + ei

Where;

$\mathbf{Y i}=$ Employment level in enterprise, represent the number of employees that are permanently employed in each enterprise (without enterprise owner).

\section{$\alpha=$ Intercept of the model}

$\beta 1, \beta 2=$ Are the slopes of the corresponding parameters of independent variables (current capital, monthly sale).

ei $=$ Disturbance term or error term. It represents all those factors which affect the level of current capital but were not taken into account.

\section{Results and Discussions}

The results of this study clearly indicates that, majority of the owners $(40.0 \%)$ of Micro Enterprises are between the age range of 3140 years as seen in Table 2 and majority of the employees (45.2\%) in the Enterprises are in the age range of 20-25 years as shown in Table 3. This shows that the employees in the Enterprises are is the working age group. The education level of the owners is so high compare to employees that, majority of the Owners $(50.0 \%)$ were graduated and majority of the employee's education level were Intermediate level. The average monthly expenditures of Owners Households are in the range of 40 thousands to 60 thousands Pakistani rupees and $52.5 \%$ of the enterprises Owners meet their Households monthly expenditures 
from his enterprise income as seen from Table 4. The information about Enterprises initial capital and current capital shows that most of the enterprises (77.5\%) initial capital was the range of Rs.40000-1035000 as seen in Table 5 and majority of the enterprises current capital are in the range of Rs.2700000-4800000 as seen in Table 6. The most of the enterprises (77.5\%) average monthly sale of each enterprise is between Rs.40000 to Rs. 1032000 as seen in Table 7.

The micro enterprises also play great role for the Owners and employees in the Income Generation. The Owners and employees get income from these enterprises. Most of the micro enterprises Owners average monthly income from his enterprise is between the Rs.53000 to Rs. 89000 as seen in Table 8 and the total monthly payment of 80 micro enterprises to employees is 4559000 . According to this information the average income of each employee from enterprise is Rs.11997.36 per month.

\begin{tabular}{|c|c|c|}
\hline Source & Frequency & Percent \\
\hline This Enterprise & 42 & 52.5 \\
\hline Enterprise + other sources & 38 & 47.5 \\
\hline Total & 80 & 100 \\
\hline
\end{tabular}

Source: Own Survey.

Table 4: Source of family income.

\begin{tabular}{|c|c|c|}
\hline Initial Capital in Rs. & Frequency & Percent \\
\hline $40000-1035000$ & 62 & 77.5 \\
\hline $1036000-2030000$ & 12 & 15 \\
\hline $2031000-3025000$ & 2 & 2.5 \\
\hline $4021000-5015000$ & 2 & 2.5 \\
\hline $7006000-8000000$ & 2 & 2.5 \\
\hline Total & 80 & 100 \\
\hline
\end{tabular}

Source: Own Survey.

Table 5: Enterprises initial capital (Rs.)

\begin{tabular}{|c|c|c|}
\hline Current Capital in Rs. & Frequency & Percent \\
\hline $400000-2600000$ & 28 & 35 \\
\hline $2700000-4800000$ & 38 & 47.5 \\
\hline $4900000-7000000$ & 8 & 10 \\
\hline $7100000-9200000$ & 4 & 5 \\
\hline $15900000-18000000$ & 2 & 2.5 \\
\hline Total & 80 & 100 \\
\hline
\end{tabular}

Source: Own Survey.

Table 6: Enterprises current capital (Rs.)

\begin{tabular}{|c|c|c|}
\hline Monthly Sale in Rs. & Frequency & Percent \\
\hline $40000-1032000$ & 62 & 77.5 \\
\hline $1033000-2024000$ & 10 & 12.5 \\
\hline $2025000-3016000$ & 4 & 5 \\
\hline $4009000-5000000$ & 4 & 5 \\
\hline Total & 80 & 100 \\
\hline
\end{tabular}

Source: Own Survey.

Table 7: Enterprise average monthly sale (Rs.)

\begin{tabular}{|c|c|c|}
\hline Monthly Income in Rs. & Frequency & Percent \\
\hline $15000-52000$ & 32 & 40 \\
\hline $53000-89000$ & 34 & 42.5 \\
\hline $90000-126000$ & 6 & 7.5 \\
\hline $127000-163000$ & 4 & 5 \\
\hline $164000-200000$ & 4 & 5 \\
\hline Total & 80 & 100 \\
\hline
\end{tabular}

Source: Own Survey.

Table 8: Owner's average monthly income from enterprise (Rs.).
Besides the role of Micro Enterprises in income generation, these enterprises also play a great role in employment creation. According to the results of model, variable Monthly sale is positive related with Employment level of the enterprise. The value of the coefficient $(\beta 1)$ of monthly sale is 1.39 which shows that, a unit change in the enterprise monthly sale leads to change in employment level by 1.39 units. The results of t-statistics and $\mathrm{p}$-value are also significant, which shows that results of coefficient are worth to accept with $99 \%$ degree of confidence. The results shows that, variable Enterprise life is also positive related with employment level. The value of the coefficient $(\beta 2)$ of enterprise life (take in years) is 0.219 which shows that, a unit change in the enterprise life leads to change employment level by 0.219 . The value of $\beta 2=0.219$ indicate that, 1 year increase in enterprise life will increase 0.219 employment level, its means that after five years the enterprise will heir additional 1 employee. The results of $t$-statistics and p-value is also significant, which shows that results of coefficient is worth to be accept with $99 \%$ degree of confidence. $R$-square $\left(R^{2}\right)=0.406$ which shows that substantial correlation exists between dependent variable (Yi) and its explanatory variables (Monthly sale and enterprise life). The value of $\mathrm{R}^{2}$ indicates that $40 \%$ variation in dependent variable has been explained by variation in independent variables.

The $65.0 \%$ of the Enterprises Owners had not had previous occupation as seen in Table 9. This information shows that, these enterprises created jobs for many individuals of the Timergara City Dir Lower. The average employees in each enterprise in Timergara City are 4.75 employees. Based on this average employees level there is 380 employees in 80 Enterprises. There is increase in employment level of Micro Enterprises from year to year, because in the start of these enterprises there were 186 employees in 80 enterprises, and the current level of employment in these enterprises 80 enterprises is 380 employees as seen in Table 10. Majority of the enterprises faced constraints during start up and during operation. The major constraints faced by the enterprises mentioned by the respondents are lack of fund to start business, Ideas or Information about the business, product market, high prices and high rent of building, market imperfection and tax on some products as seen in Tables 11 and 12 and Figure 1.

\section{Conclusion}

The current research highlighted the role of micro and small enterprises in employment creation and income generation. The role of micro and small enterprises in employment creation and income generation is increasingly recognized and has become a major playing field for policy makers. In this study an attempt is made to assess the role of micro enterprises creating employment opportunities and income generation opportunity in Timergara Dir Lower. During

\begin{tabular}{|c|c|c|}
\hline Yes/No & Frequency & Percent \\
\hline Yes & 28 & 35 \\
\hline No & 52 & 65 \\
\hline Total & 80 & 100 \\
\hline
\end{tabular}

Source: Own Survey.

Table 9: Status of previous occupation.

\begin{tabular}{|c|c|c|c|c|c|}
\hline & $\begin{array}{c}\text { No. of } \\
\text { enterprises }\end{array}$ & Min & Max & Sum & Mean \\
\hline $\begin{array}{c}\text { Number of Employees at } \\
\text { start of enterprise }\end{array}$ & 80 & 0 & 8 & 186 & 2.32 \\
\hline $\begin{array}{c}\text { Current Number of } \\
\text { Employees in Enterprise }\end{array}$ & 80 & 1 & 20 & 380 & 4.75 \\
\hline
\end{tabular}

Source: Own Survey.

Table 10: Initial and current number of employees. 
the study primary data were collected from the owners of 80 micro enterprises. For Data analysis descriptive statistical tools such as tables, frequency distribution and percentages, and inferential statistical tools; regression analysis and correlations were used to describe the responses on the role of micro enterprises. The study elaborate that there is some positive growth rate of micro enterprises in Timergara City. Regarding employment creation the results of model, variable Monthly sale and variable Enterprise life is positive related with Employment level of the enterprise. These micro enterprises created around 4.75 average numbers of employees per micro enterprise. Table 13 shows correlations between enterprise monthly sale and number of employees. The Pearson Correlation coefficient between these variables is 0.490 or 0.50 , so we conclude that there is strong positive correlation between these two variables (monthly sale and number of employees). The correlation also indicates that both variables are moving in the same direction.

Most of the enterprise owners (42.5\%) get average monthly income from Rs.53000 to Rs.89000 and each employee in the enterprise get

\begin{tabular}{|l|c|c|}
\hline Support need from the government & Frequency & Percent \\
\hline Security + Product market & 12 & 15 \\
\hline Security + Energy & 16 & 20 \\
\hline Security + Price control & 26 & 32.5 \\
\hline Product market + Energy & 6 & 7.5 \\
\hline Product market + Price control & 4 & 5 \\
\hline Energy + Price control & 16 & 20 \\
\hline Total & 80 & 100 \\
\hline
\end{tabular}

Source: Own Survey.

Table 11: Support need from the government.

\begin{tabular}{|c|c|c|c|c|}
\hline Variable & Coefficient & Std. Error & t-Statistic & Prob. \\
\hline C & 0.767741 & 0.72208 & 1.063237 & 0.291 \\
\hline Enterprise Sale & 1.39 & $2.93 \mathrm{E}-07$ & 4.735453 & 0 \\
\hline Enterprise Life & 0.219959 & 0.047376 & 4.642814 & 0 \\
\hline R-squared & $\mathbf{0 . 4 0 6 6 8 5}$ & $\begin{array}{c}\text { Mean dependent } \\
\text { variable }\end{array}$ & & 4.75 \\
\hline $\begin{array}{c}\text { Adjusted } \\
\text { R-squared }\end{array}$ & 0.391274 & $\begin{array}{c}\text { S.D. dependent } \\
\text { variable }\end{array}$ & & 3.99525 \\
\hline $\begin{array}{c}\text { S.E. of regression } \\
\text { Sum squared } \\
\text { resid }\end{array}$ & 3.11713 & Durbin-Watson stat & & 1.207124 \\
\hline F-statistic & 26.38962 & Prob(F-statistic) & & 0 \\
\hline
\end{tabular}

Table 12: Static variables of the figure.

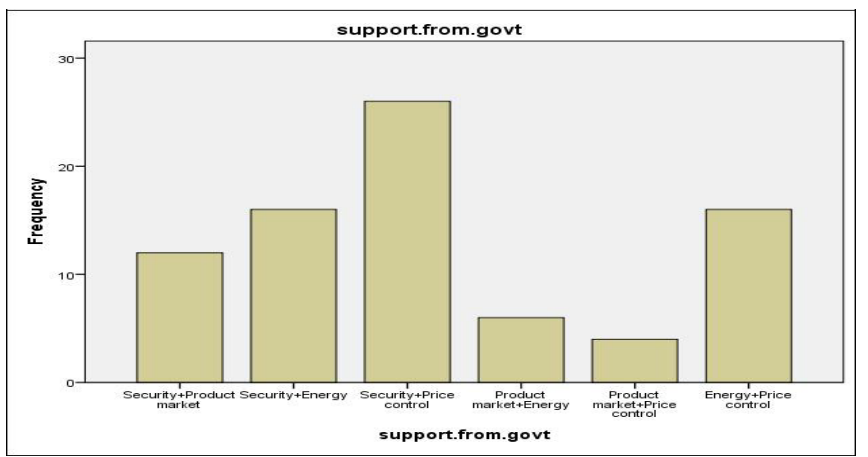

Figure 1: Model results.

Dependent Variable: Employment Level

Method: Least Squares

Date: $08 / 26 / 15$ and Time: $14: 49$

Sample: 180

Included observations: 80

\begin{tabular}{|c|c|c|c|}
\hline & & $\begin{array}{l}\text { Average total } \\
\text { monthly sale } \\
\text { (Rs.) }\end{array}$ & $\begin{array}{c}\text { No. of } \\
\text { employees in } \\
\text { enterprise }\end{array}$ \\
\hline \multirow{3}{*}{$\begin{array}{l}\text { Average total monthly sale } \\
\text { (Rs.) }\end{array}$} & $\begin{array}{l}\text { Pearson } \\
\text { Correlation }\end{array}$ & 1 & $.490^{* *}$ \\
\hline & Sig. (2-tailed) & & 0 \\
\hline & $\mathrm{N}$ & 80 & 80 \\
\hline \multirow{3}{*}{$\begin{array}{l}\text { No. of employees in } \\
\text { enterprise }\end{array}$} & $\begin{array}{l}\text { Pearson } \\
\text { Correlation }\end{array}$ & $.490^{* *}$ & 1 \\
\hline & Sig. (2-tailed) & 0 & \\
\hline & $\mathrm{N}$ & 80 & 80 \\
\hline
\end{tabular}

**. Correlation is significant at the 0.01 level (2-tailed). Source: Own Survey.

Table 13: Correlations.

average income of Rs.11997 per month. The total average monthly sale of 80 enterprises in Timergara City is Rs.61000000, these micro enterprises also create employment opportunities for the people of this area there are 380 employees in these 80 enterprises. Most of the enterprises also faced constraints during start-up time and also face constraints during operation, such as financial shortage, security, high rent and energy shortage constraints. We can get the conclusion that, micro enterprises are the most contributory businesses. Micro enterprises are most labor intensive and play important role in economic development of developing countries.

\section{Recommendations}

To conclude that, micro enterprises play a great role in reducing unemployment and also play a great role in income generation to the owners and employees. Based on the major findings a number of policy recommendations are made to improve the role of micro enterprises in contribution to employment and income generation.

\section{Provision of loan}

The availability of fund for running and expending the business operation are very necessary, but most of the enterprises owners have low fund to expend the business or to start new business. The provision of loans or credit by the governments, commercial banks and other financial institutions are important to encourage the micro enterprises. Thus, there is a need for provision of loan for business to support the micro enterprises.

\section{Provision of trainings}

Besides the provision of Loan for businesses the provision of trainings by the government with the help of training workshops and seminars for already existing enterprises owners and for new enterprises are very important. The trainings should be given depending on the business type.

\section{Rent and price control}

The high expenses of enterprises would reduce the income. Majority of them faced the problem of high rent and high prices. It is recommended to the government to control the problem of high rent and prices through different polices.

\section{Improving educational system}

The unemployment rate and low income can be reduced highly if there is a good educational policy, which encourages creating job and high productivity there by increases income.

\section{Marketing assistance}

With regard to other supports, the following measures need to encourage by the government. 
Citation: Hassan T, Ahmad B (2016) The Role of Micro Enterprises in Employment and Income Generation: A Case Study of Timergara City Dir (L) Pakistan. Int J Econ Manag Sci 5: 318. doi:10.4172/2162-6359.1000318

Page 5 of 5

- Provision of training on quality improvement and cost reduction modalities.

- Provision of information on market opportunities and appropriate/improved technologies.

- Establishment of market information centers.

\section{References}

1. State Bank of Pakistan (2005) economic survey

2. Bureau of Statistics (2014) Plaining and Development Department Government of Khyber Pakhtunkhwa, Pakistan.

3. Ministry of Finance (2012) Pakistan.

4. District Profile, report lower Dir (2014).
5. Sharafat A, Humayun R, Aamir KM (2014) The role of small and medium enterprises and poverty in Pakistan: An empirical analysis. Theoretical and Applied Economics XXI: 67-80.

6. Gallup Cyber Letter on SME's in Pakistan (2004).

7. Pakistan Bureau of Statistics (2015).

8. Micro, Small \& Medium Enterprises (2015): An engine of growth \& prosperity, journal of the Institute of Bankers Pakistan 82: 1-48.

9. Muhammad AS (2010) Micro, Small and Medium Enterprises.

10. The role of micro, small and medium enterprises in economic growth (2008), US agency for international development, USA.

11. Chaudhry SM, Kamal S (1996) Introduction to Statistical Theory I, II.

12. Government Statistics (2005) Government of Pakistan. 